\title{
Gambaran Tingkat Pengetahuan Ibu Hamil tentang Gingivitis di Puskesmas Kakaskasen Tomohon
}

\author{
${ }^{1}$ Heldin E. Kasiha \\ ${ }^{2}$ Shirley E. S Kawengian \\ ${ }^{1}$ Juliatri \\ ${ }^{1}$ Program Studi Pendidikan Dokter Gigi Fakultas Kedokteran \\ ${ }^{2}$ Bagian Gizi Fakultas Kedokteran \\ Universitas Sam Ratulangi Manado \\ E-mail: kasihaheldin@yahoo.co.id
}

\begin{abstract}
Pregnant woman are vulnerable to oral diseases. Several studies have claimed that level of knowledge can affect dental oral health. Several dental oral problems can occur in pregnant woman inter alia pregnancy gingivitis. Gingivitis during pregnancy is due to increased concentrations of estrogen and progesterone. This condition is characterized by changes in the interdental papillae which become reddish, swollen, easily bleed accompanied by pain. Additionally, the gingiva becomes particularly sensitive to toxins and irritants such as plaque and calculus resulted in inflammation of the gingiva. This study was aimed to obtain the level of knowledge about gingivitis among pregnant women. This was a descriptive study with a cross sectional design. Data were obtained by using questionnairres. There were 60 respondents in this study obtained by using total sampling technique. Data were presented in frequency distribution tables. The results showed that there where 28 pregnant women (46.7\%) with good level of knowledge and 32 woman pregnant $(53,3 \%)$ with poor knowledge. Conclusion: Pregnant women in Puskesmas Kakaskasen had poor level of knowledge about gingivitis.
\end{abstract}

Keywords: pregnant woman, knowledge, gingivitis

\begin{abstract}
Abstrak: Wanita hamil merupakan salah satu kelompok yang rentan akan penyakit gigi dan mulut. Beberapa penelitian menyatakan bahwa tingkat pengetahuan dapat memengaruhi kesehatan gigi dan mulut. Efek kehamilan pada kesehatan gigi dan mulut antara lain gingivitis kehamilan yang disebabkan oleh peningkatan konsentrasi hormon estrogen dan progesteron. Keadaan ini ditandai dengan papila interdental yang memerah, bengkak, mudah berdarah, disertai rasa nyeri dengan gingiva yang sensitif khususnya terhadap toksin maupun iritan seperti plak dan kalkulus yang berakibat lanjut terjadinya inflamasi gingiva. Penelitian ini bertujuan untuk mendapatkan gambaran pengetahuan ibu hamil tentang gingivitis. Jenis penelitian ialah deskriptif dengan desain potong lintang. Data diperoleh dengan menggunakan kuesioner dan disajikan dalam bentuk tabel distribusi frekuensi. Terdapat 60 responden yang diperoleh menggunakan total sampling. Hasil penelitian menunjukkan 28 ibu hamil (46,7\%) berpengetahuan baik dan 32 ibu hamil $(53,3 \%)$ berpengetahuan kurang. Simpulan: Tingkat pengetahuan ibu hamil terhadap gingivitis di Puskesmas Kakaskasen masih kurang.
\end{abstract}

Kata kunci: ibu hamil. pengetahuan, gingivitis

Kehamilan menyebabkan terjadinya perubahan fisiologis pada semua sistem tubuh termasuk sistem endokrin, yang dipenga- ruhi oleh hormon estrogen dan progesteron. Perubahan ini terjadi karena tubuh mempersiapkan diri untuk proses melahirkan serta 
perkembangan janin. Perubahan yang terjadi dapat memengaruhi sistem dalam tubuh yang berdampak pada fisiologi bagian-bagian tubuh termasuk rongga mulut. Pada masa kehamilan seorang ibu akan mengalami mual dan muntah sehingga terjadi peningkatan kadar asam dalam rongga mulut yang berpeluang menyebabkan terjadinya penyakit periodontal. Penyakit periodontal yang sering terjadi pada saat kehamilan yaitu gingivitis. ${ }^{1}$

Gingivitis merupakan reaksi inflamasi dari gingiva yang disebabkan oleh akumulasi biofilm pada plak di sekitar margin gingiva dan respon peradangan terhadap bakteri. Gejala klinis gingivitis ditandai dengan perubahan warna, perubahan bentuk, perubahan konsistensi, perubahan tekstur, dan pendarahan pada gingiva. Kehamilan dapat memperberat gingivitis yang dikenal dengan pregnancy gingivitis yaitu respon inflamasi berlebih dari gingiva terhadap dental plak dan perubahan hormonal yang biasa terjadi pada masa kehamilan. Gejala klinis gingivitis terlihat pada bulan kedua dan mencapai puncaknya pada bulan ke delapan. Infeksi gingiva akan bertambah buruk selama kehamilan berlangsung bila tidak dilakukan perawatan. $^{2}$

Menurut profil kesehatan Indonesia tahun 2013 penyakit gingivitis disebabkan oleh infeksi bakteri secara langsung melalui aliran darah (hematogen) maupun tidak langsung dari respon imun sistemik infeksi melalui peningkatan mediator infeksi pertahanan tubuh, dan dianggap berhubungan dengan terjadinya bayi berat badan lahir rendah (BBLR) kurang bulan. ${ }^{3}$ Ibu hamil yang mengalami gingivitis lebih berisiko melahirkan bayi BBLR kurang bulan dibandingkan dengan ibu hamil yang memiliki gingiva sehat. Terjadinya hal ini karena kurangnya pengetahuan ibu hamil mengenai kesehatan gigi dan mulut. Perilaku mengunjungi dokter gigi dipengaruhi oleh beberapa faktor, seperti faktor individu, status ekonomi, dan tingkat pengetahuan mengenai hubungan kehamilan dengan kesehatan gigi dan mulut. ${ }^{4}$
Puskesmas Kakaskasen Tomohon merupakan puskesmas yang terletak tidak jauh dari pusat kota Tomohon. Status ekonomi masyarakat Kakaskasen terbilang cukup dengan pekerjaan mereka yang merupakan pekerja kantoran dan petani. Di Puskesmas Kakaskasen Tomohon juga belum pernah dilakukan penelitian mengenai gingivitis pada saat kehamilan. Penyuluhan kesehatan gigi dan mulut juga sangat kurang dilakukan di Puskesmas Kakaskasen Tomohon. Berdasarkan uraian di atas maka penulis tertarik melakukan penelitian tentang tingkat pengetahuan ibu hamil tentang gingivitis di Puskesmas Kakaskasen Tomohon.

\section{BAHAN DAN METODE PENELITIAN}

Jenis penelitian ini ialah deskriptif dengan desain potong lintang. Penelitian dilakukan di Puskesmas Kakaskasen Tomohon pada bulan September - Oktober 2016. Populasi penelitian yaitu ibu hamil yang berkunjung ke Puskesmas Kakaskasen Tomohon pada bulan September - Oktober 2016. Responden penelitian yaitu $60 \mathrm{ibu}$ hamil yang berkunjung ke KIA Puskesmas Kakaskasen Tomohon dengan kehamilan trimester pertama, kedua, dan ketiga yang berkunjung ke KIA yang diperoleh menggunakan teknik total sampling.

Pengambilan data primer diperoleh secara langsung melalui kuesioner pada ibu hamil yang menjadi responden penelitian yang langsung di temui di Puskesmas Kakaskasen Tomohon.

\section{HASIL PENELITIAN}

Karakteristik responden penelitian berdasarkan kelompok usia terbanyak ialah kelompok usia 20-30 tahun $(73,3 \%$ ) (Tabel 1). Kelompok pendidikan terbesar ialah sarjana $(46,7 \%)$ (Tabel 2) sedangkan kelompok pekerjaan terbesar ialah ibu rumah tangga (40,0\%) (Tabel 3).

Hasil penelitian memperlihatkan bahwa jumlah responden (32 orang) yang memiliki pengetahuan kurang mengenai gingivitis lebih banyak daripada yang memiliki pengetahuan baik (28 orang) (Tabel 4). 
Tabel 1. Karakteristik responden berdasarkan kelompok usia

\begin{tabular}{ccc}
\hline Usia (tahun) & Jumlah (n) & Frekuensi (\%) \\
\hline$<20$ tahun & 6 & 10,0 \\
$20-30$ tahun & 44 & 73,3 \\
$>30$ tahun & 10 & 16,7 \\
Total & 60 & 100 \\
\hline
\end{tabular}

Tabel 2. Distribusi responden berdasarkan kelompok pendidikan

\begin{tabular}{ccc}
\hline Pendidikan & Jumlah (n) & Frekuensi (\%) \\
\hline SD & 2 & 3,3 \\
SMP & 10 & 16,7 \\
SMA & 20 & 33,3 \\
Sarjana & 28 & 46,7 \\
Total & 60 & 100 \\
\hline
\end{tabular}

Tabel 3. Karakteristik responden berdasarkan kelompok pekerjaan

\begin{tabular}{ccc}
\hline Pekerjaan & Jumlah (n) & Frekuensi (\%) \\
\hline PNS & 22 & 36,7 \\
IRT & 24 & 40,0 \\
Swasta & 14 & 23,3 \\
Total & 60 & 100 \\
\hline
\end{tabular}

Tabel 4. Tingkat pengetahuan responden

\begin{tabular}{ccc}
\hline Pengetahuan & $\begin{array}{c}\text { Jumlah } \\
(\mathbf{n})\end{array}$ & $\begin{array}{c}\text { Frekuensi } \\
(\boldsymbol{\%})\end{array}$ \\
\hline Baik & 28 & 46,7 \\
Kurang & 32 & 53,3 \\
Total & 60 & 100 \\
\hline
\end{tabular}

Persentase tertinggi dari kelompok usia yang memiliki pengetahuan baik mengenai gingivitis terdapat pada kelompok usia $<20$ tahun, diikuti oleh kelompok usia >30 tahun dan kelompok usia 20-30 tahun (Tabel 5).

Sebagian besar responden yang berpendidikan sarjana memiliki pengetahuan baik mengenai gingivitis, sedangkan sebagian besar responden yang berpendidikan SMP dan SMA memiliki pengetahuan kurang mengenai gingivitis (Tabel 6).

Responden yang bekerja sebagai PNS, sebagian besar $(68,1 \%)$ memilik pengtahuan baik mengenai gingivitis, sedangkan IRT dan pekerja swasta sebagian besar memiliki pengetahuan kurang mengenai gingivitis (Tabel 7).

Tabel 5. Distribusi responden berdasarkan usia

\begin{tabular}{|c|c|c|c|c|c|c|}
\hline \multirow{3}{*}{ Usia (tahun) } & \multicolumn{4}{|c|}{ Tingkat pengetahuan } & & \\
\hline & \multicolumn{2}{|c|}{ Baik } & \multicolumn{2}{|c|}{ Kurang } & \multicolumn{2}{|c|}{ Total } \\
\hline & $\mathrm{n}$ & $\%$ & $\mathrm{n}$ & $\%$ & $\mathrm{n}$ & $\%$ \\
\hline$<20$ tahun & 4 & 66,7 & 2 & 33,3 & 6 & 100,0 \\
\hline 20-30 tahun & 18 & 41,0 & 26 & 59,0 & 44 & 100,0 \\
\hline$>30$ tahun & 6 & 60,0 & 4 & 40,0 & 10 & 100,0 \\
\hline Total & 28 & & 32 & & 60 & 100,0 \\
\hline
\end{tabular}

Tabel 6. Distribusi responden berdasarkan pendidikan (tingkat pengetahuan)

\begin{tabular}{lcccccc}
\hline \multicolumn{1}{c}{ Pendidikan } & \multicolumn{3}{c}{ Tingkat pengetahuan } & \multicolumn{2}{c}{ Total } \\
\hline & \multicolumn{2}{c}{ Baik } & \multicolumn{2}{c}{ Kurang } & \multicolumn{2}{c}{$\%$} \\
SD & $\mathrm{n}$ & $\%$ & $\mathrm{n}$ & $\%$ & $\mathrm{n}$ & $\%$ \\
SMP & 2 & 100,0 & 0 & 0 & 2 & 100,0 \\
SMA & 2 & 20,0 & 8 & 80,0 & 10 & 100,0 \\
Sarjana & 6 & 30,0 & 14 & 70,0 & 20 & 100,0 \\
Total & 18 & 64,3 & 10 & 35,7 & 28 & 100,0 \\
& 28 & & 32 & & 60 & 100,0 \\
\hline
\end{tabular}


Tabel 7. Distribusi ressponden berdasarkan pekerjaan

\begin{tabular}{lcccccc}
\hline Pekerjaan & \multicolumn{9}{c}{ Tingkat pengetahuan } & & \\
\hline & Baik & \multicolumn{3}{c}{ Kurang } & Total & \\
\cline { 2 - 5 } & $\mathrm{n}$ & $\%$ & $\mathrm{n}$ & $\%$ & $\mathrm{n}$ & $\%$ \\
\hline PNS & 15 & 68,1 & 7 & 31,9 & 22 & 100,0 \\
IRT & 8 & 33,3 & 16 & 66,7 & 24 & 100,0 \\
Swasta & 5 & 35,7 & 9 & 64,3 & 14 & 100,0 \\
Total & 28 & & 32 & & 60 & 100,0 \\
\hline
\end{tabular}

\section{BAHASAN}

Data hasil penelitian pengetahuan responden mengenai pernah atau tidak mendengar tentang gingivitis, 46 responden $(76,7 \%)$ tidak pernah mendengar informasi tentang gingivitis, 14 responden $(23,3 \%)$ pernah mendengar tentang gingivitis, 2 responden $(14,3 \%)$ mendengar informasi tentang gingivitis melalui masyarakat di sekitar mereka, sedangkan 12 responden $(85,7 \%)$ mendengar informasi tersebut melalui TV, koran, majalah, dan internet. Tingginya persentase responden yang tidak pernah mendengar tentang gingivitis disebabkan karena beberapa faktor yaitu usia, pendidikan, dan pekerjaan.

Data hasil penelitian pada Tabel 1 menunjukkan bahwa dari 60 responden yang bersedia mengikuti penelitian sebagian besar berusia 20-30 tahun (44 responden), berusia <20 tahun sebanyak 6 responden dan berusia $>30$ tahun sebanyak 10 responden. Hal ini sesuai dengan yang diperoleh dari RISKESDAS tahun 2013 bahwa angka kehamilan wanita rata-rata berusia 20-30 tahun. 5

World Health Organization (WHO) merekomendasikaan untuk usia yang dianggap paling aman menjalani kehamilan dan persalinan ialah usia 20-30 tahun. Mengingat memajuan kemajuan teknologi saat ini sampai usia 35 tahun masih layak untuk hamil. Wanita usia 20-30 tahun dianggap ideal untuk menjalani kehamilan dan persalinan. Pada rentang usia ini kondisi fisik wanita dalam keadaan prima. Rahim sudah mampu memberikan perlindungan dan kondisi yang maksimal untuk kehamilan, dan pada umumnya secara mentalpun siap, yang berdampak menjaga dan merawat kehamilannya dengan baik. Usia 30-35 tahun sebenarnya merupakan masa transisi. Kehamilan pada usia ini masih bisa diterima asal kondisi tubuh dan kesehatan wanita yang bersangkutan, termasuk gizinya, dalam keadaan baik. ${ }^{6}$ Berdasarkan hasil penelitian ibu hamil berusia 20-30 tahun cenderung memiliki tingkat pengetahuan yang buruk tentang gingivitis; hal ini disebabkan karena kebanyakan wanita pada usia 20-30 tahun baru pertama kali mengandung yang menyebabkan masih kurangnya pengetahuan tentang gingivitis yang berdampak buruknya tingkat pengetahuan ibu hamil tentang gingivitis. ${ }^{7}$

Data hasil penelitian pada Tabel 2 menunjukkan bahwa dari 60 responden yang berpendidikan SD-SMP berjumlah 12 orang; SMA berjumlah 20 orang; dan pendidikan sarjana berjumlah 28 orang. Dari jumlah tersebut yang paling banyak memiliki tingkat pengetahuan baik yaitu pendidikan sarjana. Hal ini sejalan dengan penelitian Asiah $^{8}$ yang mengemukakan bahwa tingkat pendidikan dapat memengaruhi pola pikir seseorang. Bila tingkat pendidikan seseorang tinggi, maka cara berpikirnya akan lebih luas; hal ini ditunjukkan dengan kegiatan yang dilakukan sehari-hari.

Demografi dan kesehatan (SDKI) 2007 mencatat rerata jumlah anak yang dilahirkan ibu berpendidikan rendah berjumlah 4,1 anak, sedangkan dari ibu berpendidikan tinggi berjumlah 2,7 anak per keluarga. Begitu pula dengan angka kematian ibu tinggi, 228 kasus per 100 ribu angka 
kelahiran sedangkan kematian bayi 34 kasus dari seribu kelahiran. Data dari Demografi Indonesia menyebutkan bahwa $60 \%$ penduduk Indonesia hanya tamatan sekolah dasar atau lebih rendah. Data tersebut menunjukkan adanya pengaruh antara perbedaan pengetahuan gingivitis tentang ibu hamil yang berpengetahuan rendah dan yang berpengetahuan tinggi terhadap tingkat pengetahuan gingivitis. ${ }^{9}$

Wanita yang kurang berpendidikan lebih cenderung mengandung pada usia yang lebih muda. Sekitar 19\% wanita yang berpendidikan rendah telah mempunyai anak dibandingkan dengan $4 \%$ yang berpendidikan tinggi. Pendidikan berperan penting di dalam kehidupan berkeluarga, karena wanita yang berpendidikan tinggi mempunyai pengetahuan yang lebih luas di bandingkan yang berpendidikan rendah. ${ }^{10}$

Pendidikan merupakan dasar pengetahuan intelektual yang dimiliki seseorang. Semakin tinggi pendidikan maka akan semakin besar kemampuan seseorang untuk menyerap dan menerima informasi sehingga pengetahuan dan wawasannya luas. Selain itu pendidikan merupakan salah satu faktor yang melatarbelakangi tindakan yang dilakukan dan selanjutnya akan memengaruhi perilaku seseorang. Ada tidaknya pengaruh tingkat pendidikan terhadap tingkat pengetahuan ibu hamil tentang gingivitis ibu hamil tersebut mungkin saja terjadi karena pendidikan pada dasarnya tidak hanya dapat diperoleh dari bangku sekolah (formal) tetapi juga di lingkungan keluarga, masyarakat, dan dari media lainnya seperti majalah, berita, dll. ${ }^{11}$

Data hasil penelitian pada Tabel 3 menunjukkan bahwa dari 60 responden, yang memiliki pekerjaan sebagai PNS sebanyak 22 responden, IRT berjumlah 24 responden, dan swasta berjumlah 14 responden; yang paling banyak memiliki tingkat pengetahuan baik yaitu PNS. Hal ini selaras dengan penelitian Elisa $^{12}$ yang mengemukakan manusia adalah makhluk spesial, dimana dalam kehidupan individu satu saling berinteraksi dengan individu lain sehingga terpapar informasi. Melalui pekerjaan dan rutinitas seseorang akan berinteraksi dengan orang lain dan terpapar informasi. Berbeda halnya dengan ibu yang tidak bekerja dan hanya mendapat informasi minimal karena kurang berinteraksi dengan orang lain.

Pekerjaan merupakan suatu kegiatan atau aktivitas seseorang untuk memperoleh penghasilan guna memenuhi kebutuhan hidupnya sehari-hari. Pekerja/karyawan adalah mereka yang bekerja pada orang lain atau institusi, kantor, perusahaan dengan upah dan gaji baik berupa uang maupun barang. Pekerjaan merupakan faktor yang memengaruhi pengetahuan. Ditinjau dari jenis pekerjaan, yang sering berinteraksi dengan orang lain lebih banyak pengetahuannya bila dibandingkan dengan yang tanpa interaksi dengan orang lain. Pengalaman belajar dalam bekerja yang dikembangkan memberikan pengetahuan dan keterampilan professional serta pengalaman belajar dalam pengambilan keputusan yang merupakan keterpaduan menalar secara ilmiah dan etik. $^{13}$

Hasil penelitian menunjukkan responden dengan tingkat pengetahuan yang baik tentang gingivitis pada ibu hamil berjumlah 28 orang sedangkan responden dengan tingkat pengetahuan yang kurang sebanyak 32 orang. Hal ini sejalan dengan penelitian yang dilakukan oleh Kusuma tahun 2008 mengenai pengetahuan gingivitis pada ibu hamil yang melaporkan bahwa sebagian besar responden memiliki tingkat pengetahuan yang masih kurang. ${ }^{13}$

Semakin meningkatnya pengetahuan ibu hamil tentang gingivitis maka akan memengaruhi perilaku untuk menjaga kesehatan rongga mulut saat kehamilan. Kurangnya kesadaran yang terkait dengan pengetahuan menjadi masalah utama. ${ }^{14}$

\section{SIMPULAN}

Dari hasil penelitian dapat disimpulkan bahwa ibu hamil kelompok usia 20-30 tahun lebih banyak memiliki tingkat pengetahuan kurang. Kelompok ibu hamil berpendidikan sarjana dan kelompok dengan pekerjaan sebagai PNS lebih banyak memiliki pengetahuan baik. 


\section{SARAN}

Kepada Puskesmas dan Dinas Sosial Kota Tomohon disarankan untuk lebih meningkatkan kegiatan pemeliharaan kesehatan gigi dan mulut khususnya pada ibu hamil, misalnya memberikan edukasi kepada ibu hamil tentang gingivitis.

Bagi Dinas Kesehatan perlu adanya peningkatan sarana kesehatan gigi dan mulut di daerah Kakaskasen khususnya pada ibu hamil.

Hasil penelitian ini dapat dijadikan bahan acuan untuk penelitian lebih lanjut mengenai tingkat pengetahuan ibu hamil tentang gingivitis dengan faktor-faktor yang lebih bervariasi, dan jumlah responden yang lebih banyak.

\section{DAFTAR PUSTAKA}

1. Abdul GS. Hubungan kehamilan dan penyakit periodontal (relationship between pregnancy and periodontal disease). Jurnal PDGI. 2014;63:3-4.

2. Hidayati, Kuswardani, Rahayu G. Pengaruh kebersihan gigi dan mulut dengan status gingiva pada ibu hamil di wilayah kerja Puskesmas Andalas Kecamatan Padang Timur Kota Padang. MKA. 2012;36(2):215-24.

3. Sayuti H. Perawatan dan pemeliharaan kesehatan gigi-mulut pada masa kehamilan [Skripsi]. Medan: Fakultas Kedokteran Gigi Universitas Sumatera Utara; 2004.

4. Dwi R. Gingivitis pada ibu hamil sebagai faktor risiko terjadinya bayi berat badan lahir rendah kurang bulan Di RS Kariadi Semarang [Karya Tulis Ilmiah]. Semarang: Fakultas Kedokteran Universitas Diponegoro; 2006.
5. Riset Kesehatan Dasar. Badan Penelitian dan Pengembangan Kesehatan Kementrian Kesehatan RI, 2013; p. 68-70.

6. Yanti D. Hubungan antara umur ibu dengan kejadian operasi caesar di Rumah Sakit Cibabat. Jurnal Program Studi DIII Kebidanan Stikes Budi Luhur. 2009:12

7. Anthonie A. Faktor-faktor penyebab gingivitis pada ibu hamil yang berkunjung pada Poli KIA Puskesmas Botoh Banda Aceh [Skripsi]. Banda Aceh: Bagian Kesehatan Gigi dan Mulut Poltekkes Nanggroe Aceh; 2012.

8. Ramayanti S. Peran makanan terhadap karies gigi. Jurnal Kesehatan Masyarakat. Studi Literatur. 2013;7(2):12.

9. Srivastaka G. Essenstials of Oral Medicine (1st ed). New Delhi: JP Medical Ltd, 2008; p. 162.

10. Kementerian Kesehatan RI. Pedoman Pemeliharaan Kesehatan di Fasilitas Tenaga Kesehatan, 2012; p. 29.

11. Asiah MD. Hubungan Tingkat Pendidikan dengan Pengetahuan Kesehatan Reproduksi Ibu Rumah Tangga. skripsi Program studi pendidikan biologi FKIP Banda Aceh. 2009 h. 11

12. Elisa. Umur, pendidikan, pekerjaan dan tingkat pengetahuan ibu tentang tanda bahaya kehamilan trimester ke III. Jurnal Keperawatan Poltekes Semarang. 2014;2:87.

13. Kusuma A. Tingkat pengetahuan ibu hamil tentang gingvitis di desa Panjer, Kebumen. Dentino. 2008;II(2):21.

14. Sondang P, Harmada T. Menuju Gigi dan Mulut Sehat, Pencegahan dan Pemeliharaan. Medan: USU Press, 2008; p. 22. 